\title{
PENGARUH KOMPENSASI TERHADAP PRESTASI KERJA KARYAWAN PADA PT GARUDA AGUNG KENCANA
}

\author{
G.T. A. Putra ${ }^{1}$, I.W. Bagia ${ }^{2}$ \\ 1,2Jurusan Manajemen, Universitas Pendidikan Ganesha, Singaraja \\ e-mail: gedetresna77@gmail.com, wayan.bagia@undiksha.ac.id
}

\begin{abstract}
Abstrak
Penelitian ini bertujuan untuk pengaruh kompensasi terhadap prestasi kerja karyawan pada PT. Garuda Agung Kencana. Desain penelitian yang digunakan dalam penelitian ini adalah kuantitatif kausal. Subjek penelitian ini adalah seluruh karyawan PT. Garuda Agung Kencana. Objek penelitian ini berfokus pada variabel kompensasi dan prestasi kerja. Populasi penelitian ini berjumlah 55 orang. Pengumpulan data dilakukan dengan metode kuesioner, yang kemudian dianalisis menggunakan regresi linier sederhana. Hasil yang diperoleh dalam penelitian ini menunjukkan bahwa kompensasi berpengaruh positif dan signifikan terhadap prestasi kerja pada PT. Garuda Agung Kencana sebesar $64,6 \%$.
\end{abstract}

Kata Kunci: kompensasi dan prestasi kerja.

Abstract
This study aims to influence the compensation on work performance at PT. Garuda Agung Kencana. The research design used in this study is causal quantitative. The subjects of this study were all employees of PT. Garuda Agung Kencana The object of this study focuses on the variables of compensation and work performance. The population of this study was 55 people. Data collection was performed by questionnaire method, which was then analyzed by simple linear regression. The results obtained in this study indicate that compensation has a positive and significant effect on work performance at PT. Garuda Agung Kencana by $64.6 \%$

Keywords: work discipline and work performance.

\section{Pendahuluan}

Tingkat penggunaan transportasi roda dua yang meningkat tajam menyebabkan peningkatkan persaingan otomotif cukup tinggi maka dari itu sebuah usaha sangatlah membutuhkan Sumber Daya Manusia (SDM) yang berkualitas. Perusahaan PT Garuda Agung Kencana sebagai salah satu dealer sepeda motor merek dagang Honda dalam memenangkan persaingan hendaknya mampu mengelola SDM dengan baik. Karyawan atau SDM memegang peranan penting sebagai faktor penggerak dari seluruh kegiatan perusahaan. Hal ini dipertegas oleh Simamora, (2004) yang menyatakan SDM merupakan bagian dari organisasi dimana dapat bergerak secara terstruktur dan dapat menetapkan sebuah taktik bagi perushaan sehingga mampu mengurangi persaingan bisnis. Pada hakikatnya setiap perusahaan yang didirikan mempunyai tujuan yang sama yaitu mencari laba dan melebihi target yang sudah ditentukan. Setiap perusahaan yang menghasilkan barang atau jasa dalam rangka untuk mencapai tujuan perusahaan harus memperhatikan kualitas dari SDM yang dimilikinya.

Dalam persaingan usaha tahun ini sangatlah menuntut usaha-usaha untuk berlaku tidak pasif serta lebih tegas dalam menentukan setiap keputusan, dan melaksanakan segala taktik perusahaan sehingga dapat bersaing. Seluruh perusahaan pastinya sangat membutuhkan modal, mesin dan material. Selain itu perusahaan juga sangat memerlukan pekerja. Permasalahan prestasi kerja tidak terlepas dari apa yang diterima oleh para pekerja. Kompensasi merupakan faktor yang mampu mempengaruhi prestasi kerja karyawan. Prestasi kerja dapat meningkat apabila keseluruhan hak yang diterima oleh pekerja diterima dengan baik. Menurut Edy Sutrisno (2009) menyatakan sebuah prestasi kerja dapat meningkat jika perusahaan dapat memberikan sebuah kompensasi terhadap para karyawan. Kompensasi yang nantinya diterima 
oleh para karyawan semakin layak maka pekerja akan terdorong untuk dapat bekerja lebih baik (Suswirdiji, 2012).

PT Garuda Agung Kencana disamping menjual berbagai jenis sepeda motor Honda. PT Garuda Agung Kencana juga memiliki bengkel resmi Honda untuk memberikan pelayanan perawatan sepeda motor dan kemudahan pembelian spaerpart atau suku cadang sepeda motor Honda bagi konsumen. Data penjualan tahun 2019 di PT Garuda Agung Kencana tersebut menurun dan tidak mencapai target penjualan yang sudah ditergetkan, hal tersebut disebabkan oleh menurunnya prestasi kerja karyawan. Adapun data penjualan sepeda motor PT Garuda Agung Kencana dengan beberapa perusahaan pesaing terdekatnya. Hal ini dapat dilihat pada tabel 1.1

Tabel 1.1

Data Penjualan Sepeda Motor PT Garuda Agung Kencana, PT Mertha Buana Motor dan PT Astra International Office Sangsit 2019

\begin{tabular}{llccc}
\hline No & \multicolumn{1}{c}{ Nama Perusahaan } & $\begin{array}{c}\text { Target } \\
\text { (Unit) }\end{array}$ & $\begin{array}{c}\text { Pencapaian } \\
\text { ( Unit) }\end{array}$ & Kategori \\
\hline 1 & PT Garuda Agung Kencana & 2100 & 1483 & Tidak \\
2 & PT Mertha Buana Motor & 2500 & 2856 & Tercapai \\
3 & PT Astra International Office Sangsit & 2140 & 2143 & Tercapai \\
\hline
\end{tabular}

Data pada tabel 1.1 menunjukkan penjualan pada PT Garuda Agung Kencana yang mengalami penurunan pada tahun 2019 lebih tinggi jika di bandingkan dengan PT Mertha Buana Motor dan PT Astra International Office Sangsit. Prestasi kerja karyawan PT Garuda Agung Kencana yang tidak mencapai target penjualan tahunan. Diduga karena tidak sesuainya kompensasi yang diterima oleh karyawan dengan beban pekerjaannya.

Hasibuan (2015: 105), menyatakan prestasi kerja adalah sebuah pencapaian yang didapat oleh karyawan dalam menjalankan seluruh beban yang ditugaskan terhadapnya yang didasari atas pengalamannya, dan keuletannya serta periode waktu. Guna mengetahui tingkat prestasi kerja karyawan di PT Garuda Agung Kencana dapat dilihat dari hasil kerja, tingkat disiplin waktu dan absensi. Hasil kerja karyawan PT Garuda Agung Kencana rendah, dimana para pekerja tidak mampu mencapai target penjualan yang sudah ditentukan oleh organisasi. Disamping itu tingkat kedisiplinan karyawan dinilai kurang, dimana hal tersebut tampak pada tabel kehadiran pekerja yang sering mangkir. Diketahui banyaknya karyawan yang terlambat datang bekerja bahkan ketidakhadiran karyawan tidak disertai dengan keterangan. Disamping itu banyak karyawan yang pulang sebelum jam kerja berakhir dimana karyawan melakukan hal tersebut pada saat jam istirahat. Menurut Kadarisman (2012:132) apabila sebuah prestasi kerja terbilang tinggi, maka para pekerja haruslah diberikan sebuah achivemen berupa peningkatan gaji atapun promosi. Peningkatan gaji sangat selaras dengan kompensasi yang diberikan terhadap para pekerja. Menurut Melayu dan S.P Hasibuan 1989 menyatakan kompensasi adalah keseluruhan penerimaan dalam hal uang maupun barang yang didapat para pekerja sebagai imbalan atas seluruh hasil kerja yang tinggi.

Rendahnya kompensasi di PT Garuda Agung Kencana disebabkan oleh kurangnya kompensasi non finansial, gaji, tunjangan dan bonus yang diberikan oleh perusahaan kepada karyawan. Kompensasi non fiansial yang diberikan PT Garuda Agung Kencana kepada karyawan khususnya untuk promosi jabatan dirasakan kurang sesuai, dimana karyawan bagian sales yang telah mencapai target penjualan (khusus motor atau spaerpart) tidak memperoleh kesempatan promosi kenaikan jabatan. Karyawan yang memiliki jabatan tinggi dan sudah lama bekerja dalam perusahaan tersebut, hingga saat ini belum mendapatkan tunjangan jabatan, ketimpangan ini tentunya akan mempengaruhi prestasi kerja karyawan. Disamping itu banyak 
karyawan mengeluh mengenai gaji yang diterimanya, dimana gaji yang diterima belum sesuai dengan Upah Minimum Regional (UMR). Hal yang sama pula dirasakan karyawan untuk pemberian bonus. Bonus akan diberikan kepada karyawan yang lembur atau target penjualan yang tidak sesuai dengan harapan kayawan. Dimana karyawan diberikan bonus tepat waktu akan tetapi nominal bonus yang diberikan masih belum memenuhi kebutuhan dari beberapa karyawan. Hal tersebut membuat prestasi karyawan menurun. Menurut Edy Sutrisno (2009) menyatakan jika prestasi kerja sebuah perusahaan tinggi, perusahaan harus memberikan imbalan kepada para pekerja. Adapun tujuan penelitian ini adalah untuk menguji pengaruh kompensasi terhadap prestasi kerja pada PT Garuda Agung Kencana.

Kompensasi merupakan sebuah rasa terimakasih yang diberikan pihak organisasi terhadap para pekerjanya, dan condong akan diberikan secara berkala. Menurut Drs. Melayu dan S.P Hasibuan (1989) menyatakan menyatakan kompensasi adalah keseluruhan penerimaan dalam hal uang maupun barang yang didapat para pekerja sebagai imbalan atas seluruh hasil kerja yang tinggi. Sedangkan menurut William B. Werther dan Keith Davis (1982) menyatakan kompensasi merupakan hal yang nantinya akan diterima karyawan atas imbalan dari hasil kerja yang diselesaikannya. sebuah prestasi kerja dapat meningkat jika perusahaan dapat memberikan sebuah kompensasi terhadap para karyawan. Kompensasi yang nantinya diterima oleh para karyawan semakin layak maka pekerja akan terdorong untuk dapat bekerja lebih baik (Suswirdiji, 2012). Dapat disimpulkan bahwa kompensasi adalah sebuah imbalam atas sebuah hasil kerja yang diselesaikannya dalam bentuk peningkatan gaji dan lain lain oleh pihak perusahan. Menurut Simamora (2006: 54) indikator-indikator kompensasi yaitu: (1) Gaji adalah sebuah imbalan yang didapatkan pekerja berbentuk nominal sebagai konsenkuensi, posisinya sebagai pekerja yang memberikan hasil atas ide serta pemikiran dalam merencakan tujuan perusahaan, (2) Tunjangan, tunjangan disesuaikan dengan beban dan tanggung jawab yang dibebankan, (3) Bonus, sebuah penghargaan yang diterima pekerja sesuai dengan pencapaian yang dihasilkan, (4) Kompensasi non finasial, sebuah balas jasa yang akan diterima atas kerja keras pekerja namun tidak dalam bentuk nominal.

Hasibuan (2015:105), menyatakan prestasi kerja adalah sebuah pencapaian yang didapat oleh karyawan dalam menjalankan seluruh beban yang ditugaskan terhadapnya yang didasari atas pengalamannya, dan keuletannya serta periode waktu. Sedangkan menurut Edy Sutrisno (2009:151) yang menyatakan prestasi kerja menyatakan sebuah prestasi kerja dapat meningkat jika perusahaan dapat memberikan sebuah kompensasi terhadap para karyawan. Dapat disimpulkan bahwa pengertian prestasi kerja adalah sebuah pencapaian kerja kualitatif dan kuantitatif dengan menjalanlan seluruh beban yang ditugaskan terhadapnya. Indikator prestasi kerja menurut Edy Sutrisno (2010:152) yaitu (1) Hasil kerja, tingkat jumlah maupun kelayakan yang telah diselesaikan serta dilaksanakan, (2) Pengetahuan pekerjaan, tingkat ilmu yang berikaitan pada beban pekerjaan yang nantinya berdampak langsung terhadap hasil kerja, (3) Inisiatif, tingkat kepekaan pekerja dalam menjalankan beban tugasnya dalam menangani seluruh masalah yang ada, (4) Kecekatan mental, tingkat kelincahan pekerja dalam menerima sebuah beban pekerjaan, (5) Sikap, tingkat kepositifan pekerja dalam menjalankan beban kerja, (6) Disiplin waktu dan absensi, tingkat kehadiran serta tepat waktunya pekerja saat bekerja. Kompensasi berhubungan sangat lekat dengan prestasi kerja. Kompensasi mampu memaksimalkan prestasi kerja karena kompensasi terkandung sebuah sistem.

Untuk memaksimalkan prestasi kerja, organisasi haruslaj mampu memberikan dorongan terhadap semua pekerja, salah satunya memberikan kompensasi yang baik. Menurut Sutrisno (2009:189) menyatakan untuk memaksimalkan prestasi kerja organisasi haruslah mampu memberikan imbalan yang layak terhadap para pekerja. Hal ini juga didukung oleh penelitian empirik yang dilakukan oleh Krismasari dan Frianto (2014) yang menyatakan terdapat pengaruh yang positif dan signifikan antara kompensasi terhadap prestasi kerja karyawan. Dapat disimpulkan terdapat pengaruh terhadap prestasi kerja karyawan bilamana sebuah perusahaan dapar memberikan kompensasi yang layak terhadap pekerja maka hal tersebut akan memaksimalkan prestasi kerja pekerja di sebuah perusahaan. Berdasarkan landasan teori dan hasil penelitian sebelumnya maka hipotesis penelitian yang diajukan adalah: 


\section{$\mathrm{H}_{1}$ : Ada pengaruh kompensasi terhadap prestasi kerja PT Garuda Agung Kencana.}

\section{Metode}

Penelitian ini dilaksanakan di PT Garuda Agung Kencana yang beralamat di jalan WR. Supratman no 93, Desa Penarukan, Kabupaten Buleleng. Waktu pelaksanaan penelitian pada kegiatan pra pelaksanaan meliputi survei, pembuatan proposal hingga ujian proposal yang dilaksanakan pada bulam April 2020. Kegiatan selanjutnya adalah pelaksanaan penelitian, yang meliputi kegiatan pengumpulan data dan pengolahan data dilaksanakan pada minggu ke-4 bulan Juni 2020. Kegiatan selanjutnya adalah penyusunan laporan yang dilaksanakan pada minggu ke-2 bulan Juli 2020. Penelitian ini dilakukan untuk menguji pengaruh kompensasi terhadap prestasi kerja karyawan pada PT Garuda Agung Kencana. Rancangan penelitian yang digunakan dalam penelitian ini adalah kuantitaif kausal. Menurut Sugiyono (2014) penelitian kuantitatif kausal yaitu penelitian yang bertujuan untuk mencari hubungan antara satu variabel dengan variable lain yang mempunyai hubungan sebab akibat.

PT Garuda Agung Kencana merupakan subjek penelitian ini. Sedangkan kompensasi (X), dan prestasi kerja (Y) merupakan objek dalam penelitian ini. Populasi adalah seluruh jumlah yang nantinya akan diteliti yang mercangkup objek dan subjek yang berada pasa sebuah lingkungan yang memenuhi syarat-syarat tertentu berkaitan dengan masalah penelitian. Populasi dalam penelitian ini adalah seluruh karyawan yang masih aktif pada PT Garuda Agung Kencana dengan jumlah 55 karyawan.

Jenis data yang digunakan dalam penelitian ini adalah data kuantitatif. Data primer merupakan jenis data yang digunakan dalam penelitian ini. Data primer adalah data yang didapatkan dari orang pertama. Data yang diperoleh terkait kompensasi dan prestasi kerja yang diperoleh dari pekerja pada PT Garuda Agung Kencana. Angket dijawab langsung oleh para pekerja sedangkan untuk angket prestasi kerja diperoleh dari atasan yang menilai para karyawan. Kuesioner adalah sebuah instrumen terkumpulnya data-data yang nantinya akan dijabarkan dari indikator masing-masing variabel. Kuisioner yang digunakan untuk memperoleh data mengenai kompensasi dan prestasi kerja pada PT Garuda Agung Kencana. Instrumen yang dipergunakan pada kuesioner merupakan angket yang terdapat sebuah list pertanyaan, dimana nantinya disebarkan terhadap responden. Kuesioner adalah alat yang digunakan untuk mengumpulkan seluruh data ordinal, terkait penjabaran dari indikatoe variabel yang nantinya akan diuji terlebih dahulu keabsahannya. Untuk menguji tingkat keabsahan sebuah kuesioner dapat menggunakan uji validitas. Uji Validitas dipergunakan untuk mengetahui tingkat keabsahan suatu kuisioner. Semakin tingginya validitas sebuah instrumen menujukkan semakin baik kuisioner tersebut.

Suatu instrumen dinyatakan sah jika telah memenuhi segala persyarat pengujian validitas instrumen dengan perolehan taraf signifikansnya sebesari 5\% (Sugiyono, 2010). Syarat-syarat dalam melakukan uji validitas sebuah instrumen adalah: (1) Item dinyatakan sah jika $\rho$-value kurang dari alpha ( $\alpha$ ) maka item instrument tersebut dapat dipergunakan, (2) Item dinyatakan tidak sah jika $\rho$-value lebih dari alpha $(\alpha)$ maka item instrument tersebut tidak dapat dipergunakan. Pengujian reliabilitas berkaitan dengan masalah adanya kepercayaan terhadap instrumen penelitian. Suatu instrumen dikatakan reliabel atau andal jika jawaban responden atas pertanyaan adalah konsisten atau stabil (Sugiyono, 2010). Suatu instrumen dikatakan reliabel apabila memenuhi kriteria pengujian reliabilitas instrumen dengan menggunakan taraf signifikasi $5 \%$. Pengujian reliabilitas dalam penelitian ini mempergunakan sebuah metode yang dinamakan belah dua, metode belah dua adalah sebuah uji yang dilakukan pada item-item tersebut, kemudian ditotal, lalu mencari kesamaannya dan kemudian diteliti. Kriteria instrumen dikatakan reliabel dengan menggunakan teknik ini, koefisien reliabel $>0,60$

Penelitian ini menggunakan metode analisis Regresi Linier Sederhana yaitu statistik yang dipergunakan guna membentuk korelasi antara variabel terikat dan variabel bebas. Teknik analisis pada penelitian ini dibantu sebuab aplikasi berbasis komputer dimana dapat dengan mudah dan dapat membantu penelitian ini. Menurut Sugiyono (2014) uji signifikansi parsial (uji t) yaitu untuk mengetahui bahwa variabel bebas yaitu kompensasi secara parsial mempunyai 
pengaruh yang signifikan terhadap variabel terikat yaitu prestasi kerja. Sejalan dengan teori William B. Werther dan Keith Davis (1982) menyatakan kompensasi merupakan hal yang nantinya akan diterima karyawan atas imbalan dari hasil kerja yang diselesaikannya. sebuah prestasi kerja dapat meningkat jika perusahaan dapat memberikan sebuah kompensasi terhadap para karyawan. Kompensasi yang nantinya diterima oleh para karyawan semakin layak maka pekerja akan terdorong untuk dapat bekerja lebih baik (Suswirdiji, 2012).

\section{Hasil dan Pembahasan}

Berdasarkan uji statistik regresi linier sederhana dapat dilihat pada Tabel 4.1

Tabel 4.1

Analisis Regresi Linier Sederhana

\begin{tabular}{lccccc}
\hline Model & \multicolumn{2}{c}{$\begin{array}{c}\text { Unstandardized } \\
\text { Coefficients }\end{array}$} & $\begin{array}{l}\text { Standardized } \\
\text { Coefficients }\end{array}$ & T & Sig. \\
\hline 1 & B & Std. Error & Beta & & \\
\hline (Constant) & 3,501 & 1,235 & & 2,834 & 0,000 \\
Kompensasi &, 491 & 0,050 & 0,804 & 9,840 & 0,000 \\
\multicolumn{7}{l}{ Dependent Variabel: Prestasi Kerja } & & & \\
\hline
\end{tabular}

Dapat dibuat model persamaan regresi linier sederhana yaitu: $Y=3,501+0,491 X+\varepsilon$. Persamaan regresi tersebut dapat diinterprestasikan sebagai berikut: nilai konstanta sebesar 3,501 berarti bahwa jika kompensasi sama dengan nol, maka prestasi kerja sebesar 3,501. Nilai koefisien $\left(\beta_{1}\right)$ regresi kompensasi sebesar 0,611 berarti apabila kompensasi meningkat 1 satuan maka prestasi kerja akan meningkat sebesar 0,611. Nilai thitung $=9,840$ dengan $p$-value (sig) 0,000 $<0,05$ berarti $\mathrm{H} 0$ ditolak dan Ha diterima, karena kriteria pengujian hipotesis penelitian ini adalah apabila $p$-value (sig) 0,000 $<0,05=\mathrm{HO}$ ditolak dan $p$-value (sig) 0,000 $>0,05=\mathrm{HO}$ diterima. Hal ini berarti bahwa ada pengaruh positif dan signifikan kompensasi terhadap prestasi kerja karyawan pada PT. Garuda Agung Kencana

Tabel 4.2

Hasil Analisis Regresi Linier Sederhana

\begin{tabular}{lllll}
\hline Parameter & Koefisien & $\boldsymbol{\rho}$-value & Alpha & Keputusan \\
\hline Ryx & 0,804 & 0,000 & 0,05 & Menolak H0 \\
$\mathbf{R}^{2} \mathbf{y x}$ & 0,646 & 0,000 & 0,05 & Menolak H0 \\
$\mathbf{e}$ & 0,354 & - & - & - \\
$\mathbf{a}$ & 3,501 & 0,000 & 0,05 & Signifikan \\
$\mathbf{b}$ & 0,491 & 0,000 & 0,05 & Signifikan \\
\hline
\end{tabular}

Struktur pengaruh X terhadap Y pada PT. Garuda Agung Kencana dapat digambarkan pada Gambar 4.1 


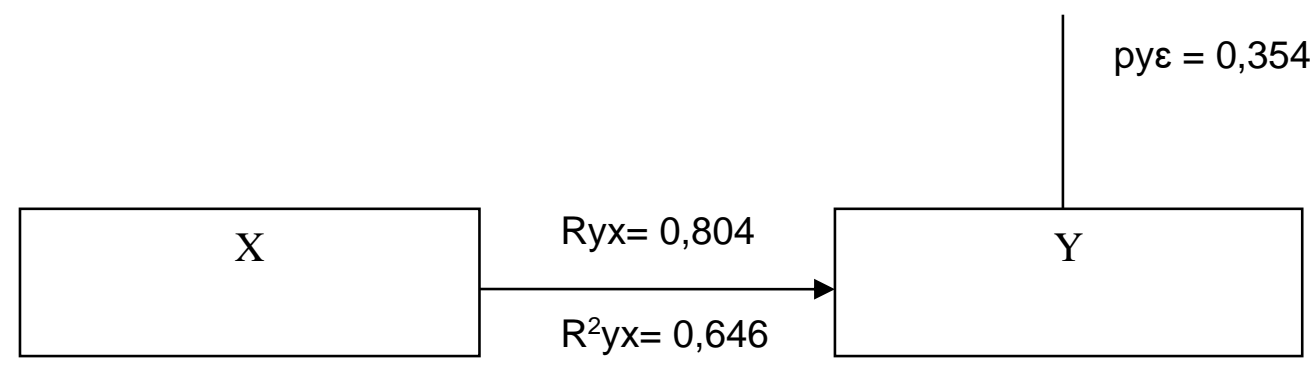

Gambar 4.1

Struktur Pengaruh $\mathrm{X}$ terhadap $\mathrm{Y}$

Dapat diinterprestasikan hubungan antar variabel sebagai berikut: Ryx menunjukkan ada hubungan $X$ terhadap $Y$ sebesar $80,4 \%$. $R^{2} y x$ menunjukkan besar sumbangan pengaruh $X$

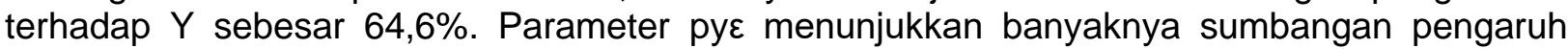
variabel lainnya terhadap $Y$ adalah $35,4 \%$.

Variabel $Y$ berpengaruh secara positif terhadap $Y$ pada PT. Garuda Agung Kencana., ditunjukkan dengan nilai $p$-value $R^{2} \mathrm{yx}=0,000$ kurang dari $\alpha(0,05)$. Besar sumbangan pengaruh $X$ terhadap $Y$ adalah 0,646 . Hasil tersebut ditujukan bahwa sebesar $64,6 \%$ variabel $Y$ dipengaruhi oleh variabel $X$, sedangkan pengaruh dari variabel lain sebesar $35,4 \%$. Berdasarkan hasil analisis regresi linier sederhana di atas jadi kesimpulan dalam penelitian ini bahwa terdapat pengaruh positif dan signifikan kompensasi terhadap prestasi kerja karyawan pada PT. Garuda Agung Kencana.

Diperolehlah sebuah hasil bahwa variabel $X$ berpengaruh signifikan terhadap $Y$ pada PT. Garuda Agung Kencana. Hal ini sejalan dengan yang disampaikan oleh Edy Sutrisno (2009:189) menyatakan prestasi kerja menyatakan sebuah prestasi kerja dapat meningkat jika perusahaan dapat memberikan sebuah kompensasi terhadap para karyawan. Kompensasi berhubungan sangat erat dengan prestasi kerja, tingginya prestasi kerja dikarenakan oleh penerimaan imbalan yang layak serta promosi jabatan. Untuk memaksimalkan prestasi kerja para pekerja, pihak organisasi haruslah memberikan sebuah timbal balik yang setara dengan hasil yang diterimanya.

Kompensasi yang diberikan perusahaan dapat diartikan sebagai yang didapatkan para pekerja atas tercapainya dan terselesaikannya seluruh beban pekerjaannya. Pemberian kompensasi ini penting untuk diperhatikan untuk kenyamanan dalam bekerja dan meningkatkan semangat kerja karyawan. Penelitian ini didukung oleh hasil penelitian yang dilakukan oleh Krismasari dan Frianto (2014).

Perusahaan yang memberikan kompensasi yang tepat akan dapat meningkatkan semangat kerja sehingga karyawan tersebut dapat memiliki prestasi kerja yang baik. Pemberian kompensasi dapat berupa kenaikan pendapatan, tunjangan, terhadap para pekerja yang mencapai target dan memiliki prestasi kerja. Dengan kompensasi tersebut, para pekerja lebih merasakan perasaan dihormati dan akan bekerja dengan nyaman. Ketidakpuasan dalam kompensasi yang dirasakan karyawan akan sangat berdampak pada kinerja sehingga dapat menyebabkan prestasi kerja menurun. Karyawan yang mendapatkan kompensasi yang sesuai akan memberikan kontribusi terbaiknya kepada perusahaan. Dengan semangat kerja yang dimiliki, karyawan akan mampu mencapai prestasi nantinya pihak perusahaan akan dengan mudah menggapai target yang ditetapkan sebelumnya.

Hasil penelitian ini telah menunjukkan bahwa $X$ berpengaruh positif dan signifikan terhadap Y. Oleh karena itu, hasil penelitian ini memberikan implikasi bahwa untuk memaksimalkan 
prestasi kerja segala pihak perlu mencermati variabel kompensasi. Pemberian imbal balik yang tepat sesuai dengan standar kerja sangat berdampak peningkatan prestasi kerja karyawan. Hal ini berarti jika pihak perusahaan ingin meningkatkan prestasi kerja maka pihak perusahaan perlu memperbaiki kompensasi yang diberikan kepada karyawan.

\section{Simpulan dan Saran}

Dapat disimpulkan bahwa, variabel $\mathrm{X}$ berpengaruh secara positif dan signifikan terhadap variabel Y di PT. Garuda Agung Kencana. Hal ini berarti prestasi kerja pekerja yang meningkat diakibatkan oleh dampak diperlayaknya sebuah kompensasi oleh pihak perusahaan. Pekerja yang memperoleh sebuah imbal hasil tinggi akan memiliki semangat bekerja dalam mengerjakan tugas-tugasnya sehingga karyawan akan mampu mencapai prestasi kerja. Saran bagi pihak Manajemen PT. Garuda Agung Kencana agar lebih memperhatikan kompensasi karyawan untuk meningkatkan prestasi kerja sehingga perusahaan mampu mencapai target yang telah ditetapkan.

Sedangkan saran bagi peneliti selanjutnya diharapkan untuk melakukan pengembangan terhadap penelitian ini dengan mempergunakan populasi yang lebih luas agar hasil penelitian lebih teruji keandalannya. Di samping itu, menguji variabel lain yang diduga kuat dapat memengaruhi variabel prestasi kerja karyawan.

\section{Daftar Pustaka}

Arikunto, Muhammad. 2006. Penyusunan Skala Psikologis. Yogyakarta: Pusaka Pelajar.

Dini Krismasari dan Agus Frianto. 2014. Pengaruh Kompensasi dan Disiplin Kerja Terhadap Prestasi Kerja Karyawan Pabrik Gula Tjoker. Jurnal IImu Manajemen, Volume 2, Nomor 4

Hanggraeni, Dewi. 2012. Manajemen Sumber Daya Manusia. Penerbit Fakulyas Ekonomi Universitas Indonesia.

Hasibuan, S. P. M. 2015. Manajemen Sumber Daya Manusia, PT. Bumi Aksara: Jakarta.

Kadarisman, M. 2012. Manajemen Pengembangan Sumber Daya Manusia. Jakarta: Rajawali pers.

Mangkunegara, Anwar Prabu. 2009. Manajemen Sumber Daya Manusia Perusahaan. Bandung: Remaja Rosdakarya.

Mondy, R. Wayne, Noe Robert M., 2011. Human Resource Management, Tenth Edition, Jilid I, Penterjemah Bayu Airlangga, M.M., Penerbit Erlangga, Jakarta.

Sugiyono. 2014. Statistika Untuk penelitian. Bandung: CV Alfabeta.

Suswardji, Edi., dkk,. 2012. Analisis Hubungan Kompensasi dengan Prestasi Kerja Karyawan pada Rumah Sakit Islam Karawang. Jurnal Manajemen 09 (3): 787-797.

Sutrisno, Edy. 2010. Manajemen Sumber Daya Manusia. Jakarta: Kencana Prenada Media Grroup

Simamora Henry. 2006. Manajemen Sumber Daya Manusia. Cetakan Kedua. Yogyakarta: STIE TKPN.

Werther, William B and Keith Davis. 1996. Human Resource and Personnel Management, $5^{\text {th }}$ edition. McGraw-Hill Internation Edition. 